\title{
Factors Affecting the Adsorption of Trivalent Chromium Ions by Activated Carbon Prepared from Waste Rubber Tyres
}

\author{
Sylvia E. Benjamin ${ }^{*}, 1$, Muhammad Ashfaq Sajjid² \\ ${ }^{1}$ Forman Christian College - A chartered University, Gulberg II, Lahore 54600, Pakistan \\ ${ }^{2}$ Obeikan Investment Group, 2nd Industrial City, Riyadh 17952, Saudi Arabia
}

\author{
A R T I C L E IN F O \\ Article history: \\ Received: 16 June, 2017 \\ Accepted: 08 August, 2017 \\ Online: 24 August, 2017
}

Keywords:

Adsorption

Chromium (III)

Tyre Activated Carbon (TAC)

\begin{abstract}
A B S T R A C T
Economic gains are generally the outcome of industrialization and consequently urbanization. However, positive fiscal index generates a negative impact on natural environment sources heaving pollutant burden on soil, air and water. Industries throw tones of contaminated water into soil and water bodies without proper treatment and create a potential threat for both living and non-living species. Chromium in trivalent state $\left(\mathrm{Cr}^{3+}\right)$ is added in water bodies and soil through waste water from tanneries, cooling water systems, chemical and pulp and paper industries. The present research work aims at the preparation of an inexpensive activated carbon prepared from non-degradable waste scrap rubber tyres. The carbon produced from scrap rubber tyres was activated by 5\% solution of $\mathrm{BaCl}_{2}$ and $0.4 \mathrm{~N}$ solution of $\mathrm{HCl}$ and verified by ethylene blue solution. The adsorption capacity of the Tyre activated carbon (TAC) was investigated for different parameters i.e., initial chromium (III) ion concentration, activated carbon dosage, contact/ stirring time and $\mathrm{pH}$. The adsorption capacity of TAC depends on the initial metal ion concentration and the TAC dose. $p H$ of the chromium solution effects the adsorption capacity of TAC due to the formation of tetra hydroxochromate(III) complexes. The results show that TAC offers a cost effective reclamation process for the removal of $\mathrm{Cr}^{3+}$ from effluent waters.
\end{abstract}

\section{Introduction}

Industrialization and urbanization at a fast rate, especially in the developed countries, is todays leading need due to rapid population growth and thus directly linked with advancements in economics. High economic gains has its beneficial as well as adverse effects. Industrial progress has intensified pollution problems worldwide. Land, air and water pollution is building up due to inefficient execution of environmental laws. One of the major concerns is water pollution caused by effluents from various industries. The present paper is an extension of the original work that presented the removal of Copper ions $\left(\mathrm{Cu}^{2+}\right)$ from industrial waste waters by TAC [1].

Economic booms have lifted up many people from agonizing poverty through industrialization. However, this has resulted in serious environmental degradation (China Water Quality Management Policy and Institutional Considerations, World Bank,

*Corresponding Author: Sylvia E. Benjamin, Forman Christian College - A chartered University, Gulberg II, Lahore 54600, Pakistan, +92 42 33342997934, Email: s_e_benjamin@yahoo.com
2006). Industries use tones of water for various processes and also release large quantities of waste water (loaded with spent chemicals and metallic residues) in the nearby lakes, rivers and canals without suitable treatment. Many areas of the world have now lost access to safe drinking water. It is estimated that 2000 children under the age of five die daily. $90 \%$ of such deaths are linked with diarrheal diseases due to intake of contaminated water and improper sanitation and hygiene conditions. A press release by UNICEF (New York, 22 March 2013) states that 783 million people do not have access to safe drinking water (comprising of China on the top with 119 million, then India, Nigeria and lastly Pakistan at the bottom with 15 million).

Release of chemicals in aquatic environment brings changes in the structure and functional properties of water species [2] and sometimes results in their total extinction. A major concern of today are the heavy metals which are toxic above certain concentration [3-4] and henceforth, a potential threat for the consumers. Severe ecological problems are arising due to the contamination of surface and ground water. Some plant species 
are able to withstand low concentrations of certain metals but generally face eradication at high levels [5]. Mostly heavy metals are carcinogenic and get incorporated in the food chain. Biomagnification and bioaccumulation [6] of heavy metals in the living beings has further aggravated the situation.

Chromium metal possesses three stable valence states i.e., 0 , +3 and +6 . Dietary $\mathrm{Cr}^{3+}$ is an essential trace mineral requirement of human body for the control of glucose metabolism by insulin [7]. is proved to be a potential carcinogen [8-9]. In [10]-[11], the authors have reported that even $\mathrm{Cr}^{3+}$, when taken as supplement, can accumulate in tissues and can bring about structural changes in DNA. A major release of $\mathrm{Cr}^{3+}$ is through tanneries and cooling water systems, and from refractory, chemical and metallurgical industrial operations. $\mathrm{Cr}^{3+}$ incorporation into the ecosystem and delivery to humans via e.g., vegetables [12] and seepage to the ground water has adversely affected human lives. It is therefore, immensely important to address this pertinent issue which needs strict implementation of $\mathrm{Cr}^{3+}$ removal systems from waste waters.

Several methods for the removal harmful ions in water are effective e.g., chemical precipitation, electrolysis, membrane technology, ion exchange etc. and are in common practice by the industries. Adsorption of ions onto a suitable adsorbent is a low cost, effective and easy method for the separation of undesired chemicals. Adsorption [13-14] i.e., physiosoprtion or chemisorption can adequately remove matter in solid, gas or liquid form. Several waste materials are reported to be good adsorbents [15-16]. Activated carbon is especially favored due to its inert nature [17-18]. In this study, activated carbon derived from scrap rubber tyres is used as an adsorbent for the removal of $\mathrm{Cr}^{3+}$ from aqueous solutions. The major aim was to test the performance of TAC as the function of adsorbent dose, $\mathrm{Cr}^{3+}$ concentration in solution, $\mathrm{pH}$ and the contact time. This will be a cost-effective utilization of non-degradable scrap rubber tyres for water purification.

\section{Materials and Methods}

\subsection{Preparation of Activated Carbon from Scrap Rubber Tyre}

Scrap rubber tyres were collected from disposal sites. These were cut into small pieces, washed several times with distilled water and dried. Pieces were then crushed and grinded in mortar and pestle. $600 \mathrm{gms}$ of the ground rubber tyres was taken in a round bottomed flask fitted with a water condenser. Dry distillated of tyres was done at $450{ }^{\circ} \mathrm{C}$. Three main fractions were obtained i.e., chars, oils plus water mixture and obnoxious gases. The residue chars were heated in a muffle furnace at $800-900{ }^{\circ} \mathrm{C}$ for 30 seconds and cooled to room temperature in desiccators. It was then soaked in $5 \% \mathrm{BaCl}_{2}$ solution for 12 hours for chemical activation and then filtered. The carbon was firstly washed with $\mathrm{HCl}(0.4 \mathrm{~N})$ and then several times with distilled water to remove the oxides and soluble impurities. The final residue sample was dried in an oven overnight at $105^{\circ} \mathrm{C}$. The dried TAC was sieved and 200 mesh size was selected for $\mathrm{Cr}^{3+}$ removal studies.

\subsection{Confirmatory Test for the adsorption capacity of TAC.}

The efficiency of TAC was tested by Methylene Blue test. $0.2 \mathrm{gm}$ of TAC was immersed in $10 \mathrm{ml}$ of $1 \%$ Methylene blue solution in a $50 \mathrm{ml}$ beaker. Same test was performed with commercially available Merck activated carbon for comparison. The absorbance was measured at $\lambda_{\max }$ of $660 \mathrm{~nm}$.

The adsorption capacity. $A C$ (\%) of TAC was calculated using following relationship:

$$
A C(\%)=\frac{C i-C t}{C i} \times 100
$$

Where

$$
\begin{aligned}
& C i=\text { initial concentration of the simulated solution } \\
& C t=\text { The concentration of solution after treatment. }
\end{aligned}
$$

The adsorption capacity (or the removal of $\mathrm{Cr}^{3+}-\%$ ) of TAC was checked on Varian spectrophotometer using an acetylene-air flame and lamp current of $7 \mathrm{~mA}$ for $\mathrm{Cr}^{3+}$ determination.

\subsection{Preparation of Chromium(III) solutions}

Chromium sulphate $\left(\mathrm{Cr}_{2}\left(\mathrm{SO}_{4}\right)_{3} \cdot 12 \mathrm{H}_{2} \mathrm{O}\right)$ salt was dried in an oven overnight at $50^{\circ} \mathrm{C}$. Stock solution of $1000 \mathrm{ppm}$ was prepared by dissolving $7.70 \mathrm{gms}$ of salt in de-ionized in a measuring flask of $1 \mathrm{~L}$. Further dilutions of $50 \mathrm{ppm}, 100 \mathrm{ppm} \& 200 \mathrm{ppm}$ solutions were made from stock solution.

The following tests were performed to check the adsorption capacity of the prepared TAC.

\subsection{Effect of TAC dosage on adsorption of chromium (III) ions}

Five volumetric flasks of $50 \mathrm{ml}$ capacity were taken. $25 \mathrm{ml}$ of $200 \mathrm{ppm}$ solution of $\mathrm{Cr}^{+3}$ ions was poured in each flask. $0.1 \mathrm{gm}$, $0.2 \mathrm{gm}, 0.3 \mathrm{gm}, 0.4 \mathrm{gm}$ and $0.5 \mathrm{gm}$ of TAC was added. The solutions were stirred for 3 hours on magnetic stirrer at $600 \mathrm{rpm}$ and then filtered. The concentration of $\mathrm{Cr}^{3+}$ left in solution after adsorption tests was checked by Atomic absorption spectrophotometry (AAS).

\subsection{Effect of chromium (III) ions concentration on adsorption by the TAC}

$25 \mathrm{ml}$ of $10 \mathrm{ppm}, 50 \mathrm{ppm}, 100 \mathrm{ppm}, 150 \mathrm{ppm}$ and $200 \mathrm{ppm}$ $\mathrm{Cr}^{3+}$ solutions were taken in five measuring flasks. $0.1 \mathrm{gm}$ of TAC was added. The solutions were stirred for $3 \mathrm{hrs}$ on magnetic stirrer at $600 \mathrm{rpm}$ and then filtered. The amount of $\mathrm{Cr}^{3+}$ remaining in solution in each flask was measured by AAS.

\subsection{Effect of contact time on the adsorption capacity of TAC}

$25 \mathrm{ml}$ of $\mathrm{Cr}^{3+}$ solution (200 ppm) was taken in five separate $50 \mathrm{ml}$ volumetric flasks (x5). TAC $(0.1 \mathrm{gm})$ was added to each flask and the solutions were stirred for different time intervals i.e., $1,2,3,4$ and 5 hours on magnetic stirrer at $600 \mathrm{rpm} . \mathrm{Cr}^{3+}$ remaining in solution after each time interval was checked by AAS.

\subsection{Effect of solution $p H$ on the adsorption capacity of TAC.}

$\mathrm{Cr}^{3+}$ solutions $(25 \mathrm{ml})$ were taken in four separate $50 \mathrm{ml}$ volumetric flasks. The $\mathrm{pH}$ of solutions was maintained at $\mathrm{pH} 4$, $\mathrm{pH} 5, \mathrm{pH} 7$ and $\mathrm{pH} 10$. TAC $(0.1 \mathrm{gm})$ was added to each flask and the solutions were stirred for 3 hours at $600 \mathrm{rpm}$. After the adsorption test each solution was filtered and the $\mathrm{Cr}^{3+}$ concentration was checked by AAS. 


\section{Results \& Discussion}

Water pollution by the industries have risen to colossal disasters in many parts of the world. The developing countries are facing tremendous ill health effects due to water contamination especially by heavy metals [19-20]. Many living species are eradicated leaving environmental issues that need remediation. This has led the scientists to find new methods and materials for survival of living beings. Adsorption of harmful chemicals and heavy metals is a cheap method for the removal of contaminants. In recent years, several adsorbents and particularly bio adsorbents [21-23] have been investigated to combat pollution arising as a consequence of anthropogenic activities. Rubber tyres are nonbiodegradable. These have no use except illegally burned to produce obnoxious fumes or dumped in tones at waste sites. We have made use of waste rubber tyres and converted it to activated carbon for the reclamation of waste water.

The efficiency or the adsorption capacity of the prepared TAC was checked by the Methylene blue test and compared with commercial Merck Activated Carbon (powdered) at $\lambda$ max of 660 $\mathrm{nm}$. The blank solution showed an absorbance of 2.707 . The dye absorbance test showed that TAC had absorbance of 0.053 and the commercial Merck Activated Carbon had absorbance of 0.035 . Thus, our prepared TAC showed good absorbance capacity for the dye.

It is envisaged that as the amount of adsorbent is increased, the removal of metal ions should also increase systematically. TAC required to effectively adsorb $\mathrm{Cr}^{3+}$ was checked by varying TAC dose for $200 \mathrm{ppm}$ concentration. The results are presented in Figure 1.

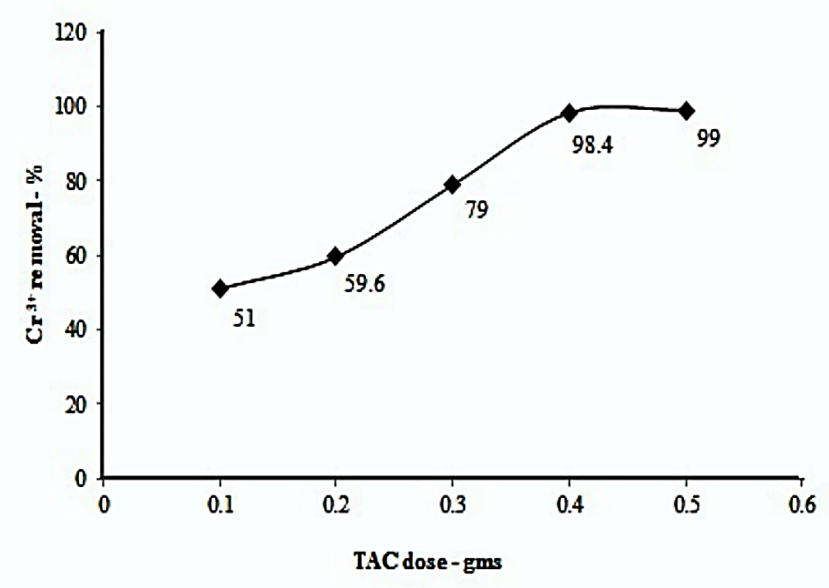

The adsorption percentage of $\mathrm{Cr}^{3+}$ (200 ppm) increases with the amount of adsorbent dose. Maximum adsorption of $99 \%$ was observed with 0.5 gm TAC of 200 mesh size at pH 6.5 (nearly neutral) after a contact period of 3 hours held at a stirring speed of $600 \mathrm{rpm}$. This important parameter has been studied by several researchers before [24-25]. In our earlier work [1], TAC proved to be an effective adsorbent for the removal of Copper (II) ions from industrial waste water. Sharma and Goyal [26] have found strong effect of adsorbent dose on removal of $\mathrm{Cr}^{3+}$ from tannery effluents at $\mathrm{pH}-4$ by Aspergillus sp biomass. Recently, Jamil et al
[27] have reported similar dose effect of Pakistani coal derived activated carbon on removal of $\mathrm{Cr}^{3+}$ from simulated solutions. The exchangeable sites for the metal ion adsorption increase with the increase in TAC dose and hence, the water is cleaned from the contaminant ions. The distribution coefficient for the TAC dose tests varies in the range of 10.4 to 198 . The Gibbs free energy $(\Delta \mathrm{G})$ changes from $-5.8 \mathrm{KJ} / \mathrm{mole}$ through $-13.4 \mathrm{KJ} / \mathrm{mole}$ telling that $\mathrm{Cr}^{3+}$ removal by adsorption is a favorable process. We selected TAC (mesh-200) dose of 0.1 gms and $\mathrm{Cr}^{3+}$ concentration of $200 \mathrm{ppm}$ for further experimentation so that variations can be studied more thoroughly.

The effect of initial metal ion concentration is shown in Figure 2.

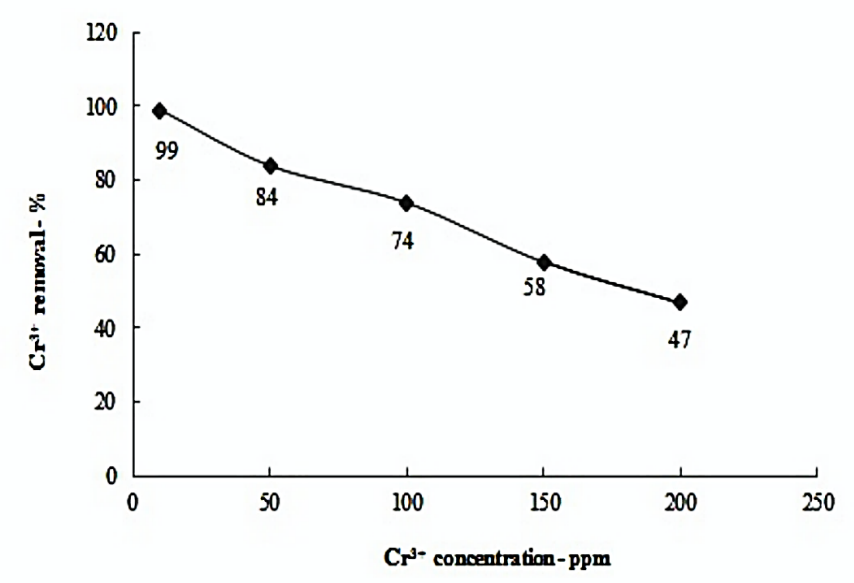

The removal of metal ions from aqueous solutions by adsorption is highly dependent on the initial metal ion concentration in solution [28-29]. The adsorption efficiency of adsorbents is applicable in a specific range of concentrations as the active site may be filled above certain concentrations. Figure 2 shows that the adsorption decreased when the concentration of the metal ions increased. Maximum adsorption of $99 \%$ was observed at low concentration of $\mathrm{Cr}^{3+}$ ions i.e., $10 \mathrm{ppm}$ and linearly declined as the initial $\mathrm{Cr}^{3+}$ concentration increased. Adsorption reduced to $47 \%$ with 0.1 gms of TAC at $6.2 \mathrm{pH}$ at contact time of 3 hours. TAC amount is the limiting factor. The exchangeable sites with a low dose amount of $0.1 \mathrm{gms}$ became saturated with $\mathrm{Cr}^{3+}$ ions at $10 \mathrm{ppm}$ concentration. The site coverage is reached and equilibrium is established. At higher initial concentrations of $\mathrm{Cr}^{3+}$ ions, the adsorption percentage decreases due to low availability of active sites. We observed the surface charge interaction phenomenon in absence of diffusion.

The contact time of adsorbent with the metal ion solution is an important factor that effects the adsorption capacity [30, 31]. $\mathrm{Cr}^{3+}$ absorption by $0.1 \mathrm{gm}$ TAC dose as the function contact time is shown in Figure 3.

The results show that as the contact time of TAC with $\mathrm{Cr}^{3+}$ solution is increased, the removal of $\mathrm{Cr}^{3+}$ also increases. Under constant stirring conditions, maximum adsorption of $\mathrm{Cr}^{3+}(50 \%)$ was observed in 3 hours. After 3 hours, no significant change in $\mathrm{Cr}^{3+}$ removal is observed. Thus, 3 hours was found sufficient for achieving equilibrium. 


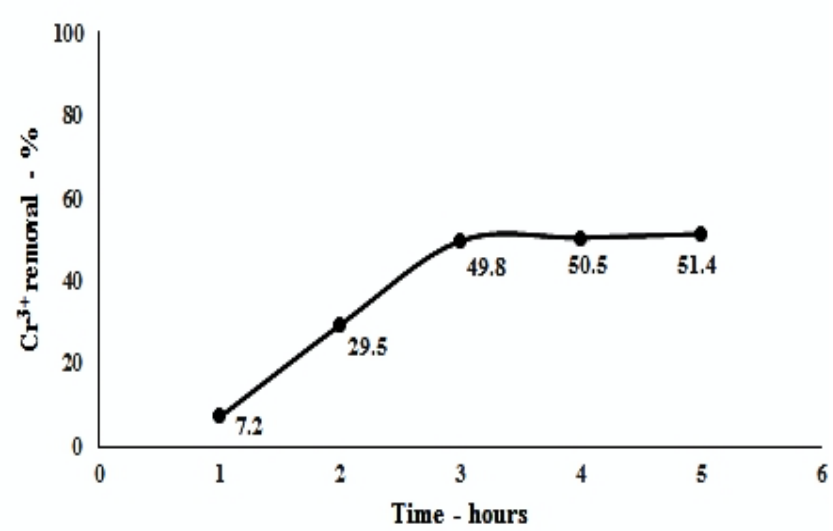

Figure.3. Effect of contact time on $\mathrm{Cr}$ (III) adsorption (initial $\mathrm{Cr}^{3+}$ concentration: 200 ppm, TAC dose: $0.1 \mathrm{~g}, \mathrm{pH}-6$, stirring speed: 600rpm)

The effect of $\mathrm{pH}$ on adsorption process is presented in Figure 4.

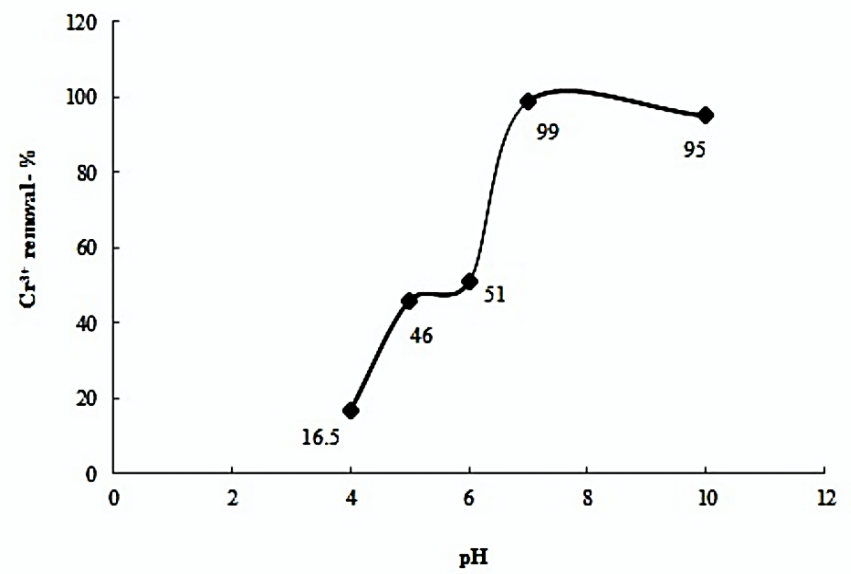

Figure.4. Effect of solution $\mathrm{pH}$ on $\mathrm{Cr}$ (III) adsorption (initial $\mathrm{Cr}^{3+}$ concentration 200ppm, contact time: 3 hours, activated carbon dose: $0.1 \mathrm{~g}$, stirring speed: 600rpm)

The removal of metal ions i.e., the absorptive capacity of adsorbents is dependent upon optimal $\mathrm{pH}$ level of the metal ions solution (32-33). In acidic medium ( $\mathrm{pH}-4), \mathrm{Cr}^{3+}$ is present as mononuclear hydrated ion. Figure 3 shows that the adsorption efficiency of TAC for $\mathrm{Cr}^{3+}$ is very low i.e., only $16.5 \%$. At acidic $\mathrm{pH}$, the hydronium $\left(\mathrm{H}^{+}\right)$ions affiliation to the adsorbents surface is responsible for TACs' poor adsorption efficiency. The adsorption efficiency of TAC for $\mathrm{Cr}^{3+}$ increases with an increase in $\mathrm{pH}$ till $\mathrm{pH}-5$ to $46 \%$. Deprotonation of metal binding sites on TAC also occurs when the solution $\mathrm{pH}$ increases. $\mathrm{The}^{\mathrm{Cr}^{3+}}$ ions are attracted to the vacant sites and hence, higher adsorption is observed. Decrease in positive charge at TAC removes repulsion and hence, improves the attraction of $\mathrm{Cr}^{3+}$ ions for active adsorption. Lyubchik et al. [34] have identified carboxylic groups on surface of activated carbons for enhancement in removal of $\mathrm{Cr}^{3+}$ at initial solution $\mathrm{pH}$ between 2 till 4 . Weak change in adsorption occurs between $\mathrm{pH} 5$ through $\mathrm{pH} 6$. At this $\mathrm{pH}, \mathrm{Cr}^{3+}$ precipitates as hydrated $\mathrm{Cr}(\mathrm{OH})_{3}$. As the $\mathrm{pH}$ rises, solubility of chromium (III) increases. Apparently, adsorption of the $\mathrm{Cr}^{3+}$ ions is maximum at pH 7 i.e., $99 \%$ which is close to $95 \%$ adsorption at
$\mathrm{pH}-10$. At alkaline $\mathrm{pH}$, adsorption efficiency is disturbed due to the precipitation of $\mathrm{Cr}^{3+}$ as tetra hydroxochromate(III) complexes, $\mathrm{Cr}(\mathrm{OH})_{4}^{-}[35] . \mathrm{Cu}^{2+}$ [1] go into hydroxide formation at high $\mathrm{pH}$. Precipitation is not as effective as adsorption as the separation of precipitates from water is cumbersome. The adsorption efficiency may increase at acidic $\mathrm{pH}$ with that activated carbon which has negatively charged surface. Dai, Ren and Tao [36] used solution $\mathrm{pH}$ for distinction between $\mathrm{Cr}$ (VI) and $\mathrm{Cr}^{3+}$ adsorption on chemically modified Chitosan. The adsorption efficiency of $\mathrm{Cr}(\mathrm{VI})$ was maximum i.e., $97 \%$ at $\mathrm{pH} 4.0$, whereas the adsorption efficiency of $\mathrm{Cr}(\mathrm{III})$ was $5 \%$. We have also observed very weak adsorption of $\mathrm{Cr}^{3+}$ ions i.e., $16.5 \%$ at $\mathrm{pH}-4$.

\section{Conclusions}

TAC is an effective low cost adsorbent for the removal of $\mathrm{Cr}^{3+}$ and $\mathrm{Cu}^{2+}$ ions. It offers treatment of impaired water at reduced energy and time consumption. The inert nature of TAC secures its reliability versus biomaterials which degrade over long time exposures. TAC almost completely removes $\mathrm{Cr}^{3+}$ ions from solutions when the metal ions are present in low concentration at $\mathrm{pH}$ 5.5. In higher alkaline medium, tetra hydroxo- $\mathrm{Cr}(\mathrm{III})$ complexes formation increases.

\section{Conflict of Interest}

The authors declare no conflict of interest.

\section{Acknowledgment}

The authors are indebted to thank Prof. Dr. P.H. Armacost, Rector, Forman Christian College - A chartered University, Lahore, Pakistan for providing the necessary laboratory facilities and $\mathrm{Mr}$. Rashid Masih, Laboratory Supervisor, Department of Chemistry, Forman Christian College - A chartered University, Lahore, Pakistan, for his constant help in doing the atomic absorption work.

\section{References}

[1] S.E. Benjamin \& Muhammad A. Sajjid, "Purification of Copper ion contaminated Industrial water by activated carbon prepared from scrap rubber tyres", Proc. 4th Int. Conf. on Energy, Environment and Sustainable Development (EESD) 2016, Nov. 1-3, 2016, Mehran Univ. of Eng. and Tech., Pakistan. http://eesd.muet.edu.pk/ sites/default/files/imagecache/ EESD_2016 paper_284.pdf

[2] M. ShahidulIslam, M. Tanaka, "Impacts of pollution on coastal and marine ecosystems including coastal and marine fisheries and approach for management: a review and synthesis", Marine Poll. Bull., 48, 624-649, 2004

[3] I. M. Madany, A.A.A. Wahab, Z. Alawi, "Trace metals concentrations in marine organisms from the coastal areas of Bahrain, Arabian Gulf", Water, Air, and Soil Poll., 91(3), 233-248, 1996.

[4] A. M. Freije, "Heavy metal, trace element and petroleum hydrocarbon pollution in the Arabian Gulf: Review", J. of the Assoc. of Arab Univ. for Basic \& Appl. Sciences (JAAUBAS), 17, 90-100, 2015. http://dx.doi.org/10.1016/j.jaubas.2014.02.001.

[5] J. Antonovics, A.D. Bradshaw, R.G. Turner., "Heavy Metal Tolerance in Plants" Adv. in Ecological Res., 7, 1-85, 1971.

[6] N.S. EL-Shenawy, N. Loutfy, M.F.M. Soliman, M. M. Tadros, A. A. Abd El-Azeez, "Metals bioaccumulation in two edible bivalves and health risk assessment", Environ Monit Assess, 188, 139, (2016). doi:10.1007/s10661-016-5145-2.

[7] T. H. Lim, T. Sargent, N. Kusubov, "Kinetics of trace element chromium(III) in the human body", Am J Physiol., 244(4), R445-54, 1983.

[8] D. L. Carlisle, D. E. Pritchard, J. Singh, S. R. Patierno, "Chromium(VI) Induces Dependent Apoptosis in Diploid Human Lung and Mouse Dermal Fibroblasts", Molecular carcinogenesis, 28(2), $111-118, \quad 2000$, DOI: 10.1002/1098-2744(200006)28:2<111:AID-MC7>3.0.CO;2-Y. 


\section{S. E. Benjamin et al. / Advances in Science, Technology and Engineering Systems Journal Vol. 2, No. 3, 1660-1664 (2017)}

[9] S. S. Wise, J. H.C. Schuler, S.P. Katsifis, J. P. Wise Sr, "Barium chromate is cytotoxic and genotoxic to human lung cells", Environ. Mutagenesis, 42 (4), 274-278, 2003.

[10] D. M. Stearns, J. J. Belbruno, K. E. Wetterhahn, "Prediction of chromium(III) accumulation in humans from chromium dietary supplements", FASEB J, 9 (15), 1650-7, 1995

[11] D. A. Eastmond, J. T. Macgregor, R. S._Slesinski, "Trivalent chromium: assessing the genotoxic risk of an essential trace element and widely used human and animal nutritional supplement", Crit Rev Toxicol., 38 (3), 17390, 2008. Doi:10.1080/10408440701845401.

[12] A. Nishat, "Flora damage assessment due to Chromium in the vicinal areas of tanneries", M.Phil Thesis, Forman Christian College - A chartered University, Pakistan, 2011.

[13] X. Chu, S. Liu, S. Zhou, Y. Zhao, "Adsorption and separation of carbon dioxide and methane in new zeolites using the Grand Canonical Monte Carlo method, Adsorption", 22, 891-899, 2016. doi:10.1007/s10450-016-9793$\mathrm{x}$.

[14] W.S.W. Ngah, M. A. K. M. Hanafiah, "Removal of heavy metal ions from wastewater by chemically modified plant wastes as adsorbents: A review", Biores. Technol., 99, 3935-3948, 2008.

[15] C. Namasivayam, D. Kavitha, "Removal of Congo Red from water by adsorption onto activated carbon prepared from coir pith, an agricultural solid waste", Dyes and Pigments, 54, 47-58, 2002.

[16] A. Demirbas, "Heavy metal adsorption onto agro-based waste materials: A review", J. of Hazard. Mat., 157 (2-3), 220-229, 2008.

[17] M. Karnib, A. Kabbani, H. Holail, Z. Olama, "Heavy Metals removal using Activated Carbon, Silica and Silica Activated Carbon Composite", Energy Procedia, 50, 113-120, 2014.

[18] T. S. Anirudhan, S. S. Sreekumari, "Adsorptive removal of heavy metal ions from industrial effluents using activated carbon derived from waste coconut buttons", J. of Environ. Sciences, 23 (12), 1989-1998, 2011.

[19] J. O. Duruibe, M. O. C. Ogwuegbu, J. N. Egwurugwu, "Heavy metal pollution and human biotoxic effects", Inter. J. of Physical Sci., 2 (5), 112118, 2007. http://www.academicjournals.org/IJPS ISSN 1992 - 1950.

[20] V. M. Chaitali, J. Dhote, "Review Of Heavy Metals in Drinking Water and their Effect on Human Health", Inter. J. of Innovative Res. in Sc., Engr. and Techol. (IJIRSET), 2 (7), 2992-2996, 2013.

[21] S.N.A. Abas, M.H.S. Ismail, M. L. Kamal, S. Izhar, "Adsorption Process of Heavy Metals by Low-Cost Adsorbent: A Review”, World Appl. Sci. J., 28 (11), 1518-1530, 2013. Doi:10.5829/idosi.wasj.2013.28.11.1874.

[22] M. Jain, V.K. Garg, K. Kadirvelu, "Equilibrium and kinetic studies for sequestration of $\mathrm{Cr}(\mathrm{VI})$ from simulated wastewater using sunflower waste biomass", J of Hazard Mater, 171 (1-3), 328-334, 2009.

[23] S. Gupta, B.V. Babu, "Removal of toxic metal $\mathrm{Cr}(\mathrm{VI})$ from aqueous solutions using sawdust as adsorbent: Equilibrium, kinetics and regeneration studies", Chem Engr J, 150, 352-365, 2009.

[24] A. Sarı, M. Tuzen, M. Soylak, "Adsorption of $\mathrm{Pb}$ (II) and $\mathrm{Cr}$ (III) from aqueous solution on Celtek clay", J. of Hazard Mater, 144 (1-2), 41-46, 2007.

[25] T. R. Chaudhury, K. M. Pathan, M. Amin, M. Ali, S. B. Quraishi, A. I. Mustafa, "Adsorption of Cr (III) from aqueous solution by ground nut shell", J. of Environ. Sci and Water Resources, 1 (6), 144 - 150, 2012.

[26] I. Sharma, D. Goyal, "Adsorption Kinetics: Bioremoval of trivalent Chromium from Tannery Effluents by Aspergillus sp Biomass, Res. J. of Environ. Sci,, 4, 1-12, 2009.

[27] A. Jamil, S. Umar, M. Salman, J. M. Anzano, "Removal of chromium (III) by using coal as adsorbent”, J. of Hazard Mater, 171 (1-3), 797-801. 2009. Doi: 0.1016/j.jhazmat.2009.06.076.

[28] L. J. Yu, S.S. Shukla, K.L. Dorris, A. Shukla, J. L. Margrave, "Adsorption of chromium from aqueous solutions by maple sawdust", J. of Hazard Mater, 100 (1-3), 53-63, 2003.

[29] A, Özer, D. Özer, A. Özer, "The adsorption of copper (II) ions on to dehydrated wheat bran (DWB): Determination of the equilibrium and thermodynamic parameters" Process Biochem, 39, 2183-2191, 2004.

[30] B. Meroufel, O. Benali, M. Benyahia, Y. Benmoussa, M.A. Zenasni, "Adsorptive removal of anionic dye from aqueous solutions by Algerian kaolin: Characteristics, isotherm, kinetic and thermodynamic studies", J. Mater. Environ. Sci. 4 (3): 482-491, (2013).

[31] M. Salem, MSM H. Sharawy, M. E. Ossman, "Kinetics modeling and Adsorption isotherm studies for $\mathrm{Cr}(\mathrm{III})$ removal using Boehmite Nanopowder", IJCBS, 3: 9-18, 2013.

[32] D. Das, M. K. Sureshkumar, K. J. Radhakrishnan, "Adsorptive removal of $\mathrm{Cr}$ (III) from aqueous solution using tripolyphosphate cross-linked chitosan beads", Radioanal Nucl Chem, 289, 275, 2011. Doi:10.1007/s10967-0111074-2.

www.astesj.com
[33] J. V. Flores-Cano, R. Leyva-Ramos, F. Carrasco-Marin, "Adsorption mechanism of Chromium(III) from water solution on bone char: effect of operating conditions", Adsorption, 22, 297, 2016. Doi:10.1007/s10450016-9771-3.

[34] S. B. Lyubchik, I. I.Perepichka, O. L. Galushko, A. I. Lyubchik, E. S. Lygina, I. M. Fonseca, "Optimization of the Conditions for the Cr (III) Adsorption on Activated Carbon", Adsorption, 11, 581, 2005. Doi:10.1007/s10450-005-5616-1.

[35] N. Torapava, A. Radkevich, D. Davydov, A.Titov, I. Persson, "Composition and Structure of Polynuclear Chromium(III) Hydroxo Complexes", Inorg. Chem., 48 (21): 10383-10388, 2009. DOI: 10.1021/ic901539g

[36] J. Dai, F. L. Ren, C. Y. Tao, "Adsorption of Cr(VI) and Speciation of $\mathrm{Cr}(\mathrm{VI})$ and $\mathrm{Cr}$ (III) in Aqueous Solutions Using Chemically Modified Chitosan", Int J. Environ. Res. Public Health, 9, 1757-1770, 2012 Doi:10.3390/ijerph9051757. 